\title{
The Effect of Work Stress, Work Load and Work Environment on Job Satisfaction And It's Implication on The Employee Performance of Aceh Investment And One Stop Services Agency
}

\author{
Aris Munandar ${ }^{1}$, Said Musnadi², Sulaiman ${ }^{3}$ \\ Magister Manajemen Program Pascasarjana Universitas Syiah Kuala Banda Aceh ${ }^{1}$ \\ Fakultas Ekonomi Universitas Syiah Kuala ${ }^{2,3}$ \\ \{aris.munandar@gmail.com\}
}

\begin{abstract}
The purpose of the study is to investigate the effect of work stress, workload and work environment on job satisfaction and its impact on the employee performance of DPMPTSP Aceh. The sample of the study is 138 civil servants of the institution. Data collected by questionnaire, and structural equation model (SEM) is operationalized to analyze the data. The study found that work stress has a negative and significant effect on job satisfaction and employee performance. On the contrary, both workload and work environment have a positive and significant effect on job satisfaction and employee performance. Furthermore, job satisfaction has a positive and significant impact on employee performance. The existence of job satisfaction mediates the effect of workload and work environment on employee performance. Conversely, the variable doesn't mediate the effect of work stress on employee performance.
\end{abstract}

Keywords: Employee's Performance, Job Satisfaction, Work Stress, Work Load, and Work Environment

\section{Introduction}

Aceh Investment and One Stop Services Agency (whereby; DPMPTSP Aceh) is one of the Aceh's government work units which is expected to contribute positively to the development of Aceh. The existence of these institutions is very important for Aceh's development due to its function is directly related to licensing and investment which in turn is expected to have an impact on economic growth in this area. The important role of investment in encouraging the regional economy has been proven by a number of researchers [1]. Without the ease of investment, economic development in the regions will experience difficulties [1].

The importance of the role of investment in encouraging the progress of investment in the province implies that the Aceh government must be able to improve the performance of the DPMPTSP Aceh in carrying out its duties and functions in accordance with what has been determined. Therefore, in carrying out its operational activities, it needs to be supported by employees who not only have the ability and work skills that are truly in accordance with their fields, but also have the desire to achieve better performance. This is due to the increase in the performance of the institution which is largely determined by the improvement in the performance of its employees. 
Given the importance of employee performance in improving the performance of government agencies in the province such as the Aceh DPMPTSP, improving employee performance is one of the important parts in achieving the objectives of HR management in the agency. Until now, there have been various ways that government agencies have done to improve the performance of their employees, including through education and training, short courses and other activities that are oriented towards improving performance. However, employee performance is basically related to a number of factors. The factors intended in this case are limited only to job satisfaction, work stress, workload, and work environment.

Job satisfaction is related to satisfaction and dissatisfaction in an employee's self towards everything related to his job. The relationship between employee performance and satisfaction logically can be explained that employees find satisfaction in work, tend to carry out work seriously and ultimately have an impact on their performance in carrying out their duties. Satisfaction felt by employees in the workplace will improve the performance of the employees concerned [2], [3] also informed that escort performance was influenced by job satisfaction.

Furthermore, work stress reflects a dynamic condition that causes employees to be faced with opportunities, constraints, and demands which are then related to the difference between conditions that are considered ideal (desired conditions) on the one hand and perceived results on the other. The difference between the two makes employees faced with uncertainty [4].

As explained above, employee performance can be influenced by workload. The workload is related to the employee's assessment of the workload that they must complete in accordance with the target and the predetermined work time [5], [6] states, the workload is a task that must be performed by an employee in a certain period of time. Workloads that are too large can cause performance to decline [7]. This means that the workload can have an impact on employee performance. The higher the workload, especially when the workload creates difficulties for employees to solve it, then the employee's performance will tend to decline.

Finally, the work environment refers to everything physical and non-physical that exists around employees that can affect their ability to carry out their tasks [8]. The work environment needs special attention from the management because it can directly affect the ability of employees to carry out their duties. The link between the work environment and employee performance is stated by Abdul \& Awan [9] that a good working environment will be able to encourage employee performance improvement. This is supported by the findings of Mathews $\&$ Khann [10] that the environment has a significant effect on employee performance. Not only affects employee performance, but the work environment can also have an impact on the formation of job satisfaction. This was revealed by Bakotic \& Babic [11] that employee job satisfaction is closely related to their perception of the work environment.

The results of a survey of employees of the Aceh DPMPTSP indicate that they have a relatively different performance from each other. As stated earlier, theoretically job satisfaction and employee performance can be influenced by work stress, workload, and perception of the work environment. This study is intended to highlight the influence of work stress, workload and work environment on job satisfaction and its implications for the performance of the agency's employees.

\section{Literature Review}

\section{Effect of the job stress on job satisfaction}

Handoko [12] states that work stress has a "functional" role and a "dysfunctional" role in encouraging the formation of job satisfaction. When the intensity of work stress increases, the 
condition can cause work discomfort. Employees with relatively high-stress levels are usually indicated by a number of indicators such as insomnia, frequent dizziness and may lose motivation to carry out their work. So that these conditions have an impact on satisfaction and dissatisfaction in surveying employees of the Aceh DPMPTSP indicating that they have a relatively different performance from each other. As stated earlier, theoretically job satisfaction and employee performance can be influenced by work stress, workload, and perception of the work environment. This study is intended to highlight the influence of work stress, workload and work environment on job satisfaction and its implications for the performance of the agency's employees.

\subsection{Effect of the workload on job satisfaction}

The workload that is too large is too heavy can have a negative impact on job satisfaction. Workload refers to the employee's assessment of the work they do [5]. Manuaba [6] states, workloads reflect the views of employees on the work they complete in a certain period of time. High workloads cause performance to decline [7].

Job satisfaction perceived by an employee can be a determinant or determinant of the success of the employee in completing the workload given. The perceived workload is too heavy and can have a negative impact on the formation of job satisfaction. Likewise, vice versa, workloads that are too light can also affect employee satisfaction at work. Moreover, some employees want to be faced with job challenges, and their success in completing these challenges becomes one of the forming factors of their job satisfaction. Thus, it can be explained that the assessment of workload can affect job satisfaction.

\subsection{Effect of the work environment on job satisfaction}

Assessment of the work environment can have an impact on employee job satisfaction. In general, every employee wants a good work environment. The better the assessment of the work environment the higher job satisfaction. So that an assessment of the work environment can have an impact on job satisfaction. Employees who have a good perception of their work environment will tend to maintain their existence in the work environment so that it has an impact on the formation of high work loyalty.

The influence of the work environment on job satisfaction is proposed by Bakotic \& Babic [11] that there is a close relationship between the two variables. This is also reinforced by the research findings of Jain \& Kaur [13] which concluded that the work environment can have an impact on job satisfaction. Research by Fachreza, Musnadi, \& Majid [14] also proves the influence of the work environment on performance.

\subsection{Effect of the job stress on the employee's performance}

Until now there have been a number of studies that have analyzed the relationship between stress and performance[4]. Stress can have a positive and negative impact on employee performance [15]. Suprihanto [16] argues that the relationship between performance and job stress levels can be explained that when employees experience stress levels too low or too, then these conditions can cause the performance of these employees to be low. 


\subsection{Effect of the workload on the employee's performance}

Workload refers to a number of jobs that must be completed by employees based on the responsibility and authority that has been given to the employee [5]. Manuaba [6] states, workload reflects the task or work that must be done by a person or group of people within a certain time horizon.

High workloads cause performance to decline [7] This means that the intensity of the workload of an employee can have an impact on the performance of the employee. The higher the workload, especially when the workload creates difficulties for employees to solve it, then the employee's performance will tend to decline.

\subsection{Effect of the work environment on the employee's performance}

The work environment can affect employee performance. This is because the work environment is an integral part of the work that is charged to employees. Employees who are in a relatively good working environment will tend to feel happy and comfortable in carrying out their work compared to employees who are in an unfavorable work environment. The influence of the work environment on employee performance has been proven by previous researchers. Naharuddin \& Sadegi [17] in their research in Malaysia found that the work environment has a significant influence on employee performance. Kiruja \& Mukuru [18] research in Kenya and the results of empirical studies conducted by Mathews \& Khann [10] in manufacturing companies in India also found that the work environment has a positive impact on employee performance.

The description above informs that basically, the work environment is a determinant of employee performance. The better an employee's assessment of his work environment, the better the performance of the employee concerned. Conversely, if the work environment is considered poor, it will adversely affect employee performance [19].

\subsection{Effect of job satisfaction on the employee performance}

Job satisfaction has a positive effect on employee performance and ultimately has a positive impact on organizational performance [3]. Research by Nasution, Musnadi, \& Faisal [20] also provides empirical evidence that job satisfaction can affect performance.

\section{Research Methods}

The research was conducted on DPMPTSP Aceh. The main focus of the research relates to the causal relationship between job satisfaction and agency performance on the one hand which is then associated with work stress, workload and their perception of the work environment on the other. In this study, job satisfaction is not only used as an endogenous variable for work stress, workload, and assessment of the work environment but also used as an intervening variable between the three exogenous variables with employee performance.

The research sample consisted of 138 civil servants working in the public agency. Data was collected through questionnaires containing closed questions. Furthermore, SEM-Amos is used to analyze the causality relationship between variables. 


\section{Result and Discussion}

\subsection{Analysis of the effect of work stress, work load and work environment on job satisfaction}

Job stress can significantly affect the job satisfaction of Aceh DPMPTSP employees. It is represented by an estimated coefficient of -0.274 and a p-value of $0.004<0.05$. This means that increased job stress can have an impact on reducing employee job satisfaction. Employees with relatively high-stress levels will tend to have low job satisfaction. Conversely, when employees experience low-stress levels, job satisfaction will increase.

Furthermore, the workload can encourage increased job satisfaction with an estimated coefficient of 0.359 and $\mathrm{p}$-value $=0.001<0.05$. This indicates that the workload can encourage employees to work better. They are motivated to carry out tasks according to the workload given. When an employee has a workload relatively little or no workload at all, the employee's performance will be low. This is what makes the workload have a positive impact on employee performance. The work environment can also encourage an increase in employee performance with an estimated coefficient of 0.578 and a p-value of 0.001 . Improving the quality of the work environment can directly improve employee performance.

\subsection{Analysis of the Effect of Job Stress, Workload and Work Environment on Employee Performance}

Job stress has a negative impact on the formation of the performance of Aceh DPMPTSP employees. This is indicated by the value of the work stress estimation coefficient on the negative performance value of -0.213 . On the other hand, workload and work environment have a positive influence on the performance of the agency's employees with estimated coefficients of 0.248 for workload and 0.418 for the work environment. The value of the p-value of the two variables is 0.015 for work stress, 0.001 for workload and 0.001 for the work environment. Furthermore, the critical value (C.R) for the three variables is also greater than 2.00 . This means that work stress can encourage a decrease in employee performance and conversely the workload and work environment have a positive impact on improving the performance of Aceh DPMPTSP employees. Increasing the intensity of work stress has an impact on decreasing employee performance. Conversely, an increase in workload and improvement in the work environment can encourage employee performance improvement.

\subsection{Analysis of the Effect of Job Satisfaction on Employee Performance}

Job satisfaction is positive and can significantly influence the performance of Aceh DPMPTSP employees. Statistically, the positive and significant influence is indicated by the estimated coefficient of job satisfaction on employee performance of 0.139 and $p$-value of 0.019 $<0.05$ and the critical value $(\mathrm{CR})$ of $2.321>2.00$. This provides empirical evidence that job satisfaction in an employee has an impact on improving employee performance. Conversely, when employee job satisfaction decreases, the condition can cause a decrease in performance. So that it can be understood that between employee satisfaction and performance has a direct relationship. 


\subsection{Analysis of the Effect of Job Stress on Employee Performance Through Job Satisfaction}

The influence of organizational commitment on employee performance can occur indirectly, also indirectly through job satisfaction. As explained earlier, the effect of work stress directly on employee performance is 4.54 percent (negative). Furthermore, the existence of job satisfaction in mediating the causality relationship between the two variables makes this effect greater, which is equal to 3.81 percent (negative). This means that the existence of job satisfaction strengthens the effect of work stress on the performance of Aceh DPMPTSP employees. So that implicitly can be interpreted that job satisfaction mediates the effect of stress on performance.

\subsection{Analysis of the Effect of Workload on Employee Performance Through Job Satisfaction}

The effect of workload on employee performance can occur directly, as well as indirectly through job satisfaction. As explained earlier, the workload directly affects employee performance by 6.15 percent. Furthermore, the indirect influence (by involving job satisfaction as an intermediary), the effect becomes smaller, amounting to 4.99 percent. This indicates that job satisfaction is not able to strengthen the influence of workload on the performance of Aceh DPMPTSP employees.

\subsection{Analysis of the Effect of the Work Environment on Employee Performance Through Job Satisfaction}

The effect of the perception of the work environment on employee performance, in addition, can occur directly, also indirectly through job satisfaction. As explained earlier, the influence of the work environment directly on the formation of employee performance is 17.47 percent. Furthermore, the indirect effect of these variables on employee performance with job satisfaction as an intermediary variable shows a smaller number of 8.03 percent. This means that job satisfaction cannot strengthen the influence of the work environment on employee performance Aceh DPMPTSP.

\section{$5 \quad$ Research Implications}

The results of this study that present empirical evidence about the negative effects of work stress on job satisfaction and employee performance are consistent with the theoretical foundation previously stated. Robbins [4] argues that, the relationship between work stress and inverted U-shaped performance. When work stress experienced by employees is relatively low, their satisfaction and performance increases. Furthermore, when stress levels are relatively high and after reaching a certain level, increased stress results in a decrease in employee satisfaction and performance. As explained earlier, the stress level of Aceh DPMPTSP employees is relatively high, and this has a negative effect on the satisfaction and performance of the agency's employees. This indicates that the findings of this study are consistent with Robbins's opinion above.

The findings of this study indicate a positive impact on the work environment on employee performance in accordance with the findings of research by Bakotic \& Babic [11] and Jain \& Kaur[13] which also concluded that there is a unidirectional relationship between 
employee performance and the work environment. This finding is also consistent with the results of Kiruja \& Mukuru[18] research in Kenya, and the results of empirical studies conducted by Mathews \& Khann [10] in manufacturing companies in India also prove the positive influence of the work environment on employee performance.

\section{Conclusion And Recommendations}

\subsection{Conclusion}

Job stress is a determining factor for job satisfaction and performance of Aceh DPMPTSP employees. Increasing the intensity of work stress can significantly reduce job satisfaction and performance of the agency's employees. Furthermore, the assessment of workload and their work environment positively impacts on job satisfaction and performance of Aceh DPMPTSP employees. This finding implicitly informs that the workload given to employees is still at the limit of their ability to carry out their duties.

Job satisfaction encourages the increased performance of Aceh DPMPTSP employees. When employees satisfied with their job, their performance will increase. Conversely, a decrease in job satisfaction can have an impact on decreasing their performance in completing their tasks. Job satisfaction is not an intermediate variable between work stress and the performance of Aceh DPMPTSP employees. Even though the results of testing using SEM indicate that work stress directly impacts performance degradation, but by involving job satisfaction as an intermediate variable, work stress does not have a significant effect on employee performance. So that job satisfaction is not a mediating variable between these two variables.

Workload affects the performance of Aceh DPMPTSP employees indirectly through job satisfaction as an intermediary variable. The intervening effect of job satisfaction as an intervening variable between these two variables is partial intervening. Furthermore, the work environment also affects the performance of the agency's employees with job satisfaction as their "transmission channel." The mediating effect of job satisfaction as an intermediary between the two variables is partial mediation.

\subsection{Recommendation}

The Head of the Aceh DPMPTSP must be able to improve the performance of his employees. Efforts to improve employee performance must be oriented towards increasing the ability of employees to complete tasks assigned to them, the ability to cooperate in employees both in their relationships with fellow colleagues and between employees and superiors. Efforts to improve the ability to complete tasks can be done by improving work skills and abilities through education and training. Furthermore, efforts to increase the capacity of cooperation can be carried out through joint activities among employees, both formal and informal (outside working hours) so that intimacy among employees is built..

The head of the Aceh DPMPTSP must strive to improve employee job satisfaction. Referring to the research findings, an increase in employee job satisfaction should be emphasized in the efforts of superiors in interacting well with their employees. Bosses must acknowledge the success of employees in completing the tasks they are working on. Such recognition can be in the form of appreciation or praise so that employees feel their hard work is morally valued. In addition, increasing employee job satisfaction is important by increasing personal relationships among employees, especially between employees and superiors. 


\section{REFERENCES}

[1] K. Amri, "Infrastruktur transportasi dan kepadatan penduduk dampaknya terhadap pendapatan per kapita: Panel data evidence dari sembilan provinsi di sumatera," J. Ekon. Manaj. dan Bisnis, vol. 2, no. 2, pp. 438-450, 2014.

[2] F. Luthans, Organizational behavior, McGraw-Hill, Inc, Seventh. McGraw-Hill, Inc., 2015.

[3] N. N. Chong, D. N. Van2, and T. H. Huu, "Effects of motivation on employees' performance at petrovietnam nghe an construction joinst stock corporation," Am. J. Bus. Manag., vol. 2, no. 2, pp. 160-164, 2013.

[4] S. P. Robbins, Perilaku organisasi: Konsep kontroversi, aplikasi, 2nd ed. Jakarta: Prenhallindo, 2012.

[5] M. R. S. Wefald, T. C. Savastano, and R. G. Downey, A structural model of workload, job attitudes, stress, and turnover intentions. 2012.

[6] A. Manuaba, Ergonomi dalam industri. 2010.

[7] Lisnayetti and M. H. Basri, "Beban kerja dan kinerja dosen poltekes Padang," 3, 2006.

[8] A. S. Nitisemito, Manajemen personalia, 3rd ed. Jakarta: Ghalia Indonesia, 2012.

[9] P. Abdul and G. Awan, "Impact of working environment on employee's productivity : A case study of banks and insurance companies in Pakistan," Eur. J. Bus. Manag., vol. 7, no. 1, pp. 329-346, 2015.

[10] C. Mathews and I. K. Khann, "Impact of work environment on performance of employees in manufacturing sector in India: Literature review," Int. J. Sci. Res., vol. 5, no. 4 , pp. 852-855, 2016.

[11] D. Bakotic and T. Babic, "Relationship between working conditions and job satisfaction: The case of croatian shipbuilding company," Int. J. Bus. Soc. Sci., vol. 4, no. 2, pp. 206213, 2013.

[12] T. H. Handoko, Manajemen personalia dan sumberdaya manusia. Yogyakarta: BPFEUGM, 2012.

[13] D. R. Jain and S. Kaur, "Impact of work environment on job," Int. J. Sci. Res. Publ., vol. 4, no. 1, pp. 1-8, 2014.

[14] Fachreza, S. Musnadi, and M. S. A. Majid, "Pengaruh motivasi kerja, lingkungan kerja dan budaya organisasi terhadap kinerja karyawan dan dampaknya pada kinerja bank acehsyariah di kota Banda Aceh," J. Magister Manaj., vol. 2, no. 1, 2018.

[15] N. Ellyzar, M. Yunus, and Amri, "Pengaruh mutasi kerja, beban kerja dan konflik inerpersonal terhadap stress kerja serta dampaknya pada kinerja pegawai BPKP perwakilan Provinisi Aceh,” J. Magister Manaj., vol. 1, no. 1, 2017.

[16] J. Suprihanto, Perilaku organisasional. Sekolah Tinggi Ilmu Ekonomi YKPN; Yogyakarta, 2003.

[17] N. Naharuddin and M. Sadegi, "Factors of workplace environment that affect employees performance: A case study of Miyazu Malaysia," Int. J. Indep. Res. Stud., vol. 2 , no. 2 , pp. 66-78, 2013.

[18] E. Kiruja and E. Mukuru, "Effect of motivation on employee performance in public middle level technical training institutions in Kenya," Ijame, vol. 2, no. 4, 2018.

[19] T. Jayaweera, "Impact of work environmental factors on job performance, mediating role of work motivation: A study of hotel sector in England," Int. J. Bus. Manag., vol. 10, no. 3, pp. 271-278, 2015.

[20] E. H. Nasution, S. Musnadi, and Faisal, "Faktor-faktor yang mempengaruhi kepuasan kerja dan dampaknya terhadap kinerja pegawai kanwil direktorat jenderal kekayaan 
negara Aceh,” J. Magister Manaj., vol. 2, no. 1, pp. 123-134, 2018. 